\title{
Predicting surgical outcome in intractable epilepsy using a computational model of seizure initiation
}

\author{
Nishant Sinha ${ }^{1 *}$, Justin Dauwels ${ }^{1}$, Yujiang Wang ${ }^{2}$, Sydney S Cash ${ }^{3}$, Peter N Taylor ${ }^{2}$ \\ From 24th Annual Computational Neuroscience Meeting: CNS*2015 \\ Prague, Czech Republic. 18-23 July 2015
}

A third of patients with epilepsy are refractory to antiepileptic drug treatment. For some of these patients with focal epilepsy, better seizure control can be achieved by surgical treatment in which the seizure focus is localized and resected while avoiding crucial cortical tissues. However, approximately $30 \%$ of the patients continue to have seizures even after surgery. In other words, reliable criteria for patient's outcome prediction are absent. Computational

Table 1 Prediction of surgical outcomes

\begin{tabular}{|c|c|c|c|c|c|}
\hline No. & $\begin{array}{l}\text { Age group } \\
\text { at onset }\end{array}$ & $\begin{array}{l}\text { Age group } \\
\text { at surgery }\end{array}$ & Surgical Resection & $\begin{array}{c}\text { Outcome } \\
\text { (Engel Class) }\end{array}$ & Predicted Outcome \\
\hline 1 & $21-30$ & $21-30$ & Right Temporal lobe & Seizure Free (II) & Good outcome \\
\hline 2 & $41-50$ & $41-50$ & Right Temporal lobe & Seizure Free (I) & Good outcome \\
\hline 3 & $21-30$ & $21-30$ & Left Cingulate & Seizure Free (I) & Bad outcome \\
\hline 4 & $41-50$ & $41-50$ & Left Temporal & Seizure Free (I) & Good outcome \\
\hline 5 & $11-20$ & $11-20$ & Right Parietal & Seizure Free (I) & Good outcome \\
\hline 6 & $51-60$ & $51-60$ & $\begin{array}{l}\text { Amygdalohippocampectomy } \\
\text { Left Medial Frontal Lobe }\end{array}$ & Seizure Free (I) & Bad outcome \\
\hline 7 & $11-20$ & $11-20$ & $\begin{array}{l}\text { Right anterior-superior frontocortical } \\
\text { Right Temporal Lobe, Amygdalohippocampectomy }\end{array}$ & Seizure Free (I) & Good outcome \\
\hline 8 & $11-20$ & $11-20$ & Left occipital brain lobe & Seizure Free (I) & Bad outcome \\
\hline 9 & $31-40$ & $31-40$ & Right frontal lobe & Seizure Free (I) & Good outcome \\
\hline 10 & $1-10$ & $1-10$ & $\begin{array}{l}\text { Left lateral frontal cortex, } \\
\text { Left anterior frontal cortex } \\
\text { Mesial left frontal cortex }\end{array}$ & Seizure Free (I) & Bad outcome \\
\hline 11 & $21-30$ & $21-30$ & Left FrontoTemporal & Not Seizure Free & Bad outcome \\
\hline 12 & $31-40$ & $31-40$ & Right Temporo-Occipital Region & Not Seizure Free (IV) & Bad outcome \\
\hline 13 & $21-30$ & $21-30$ & Right Temporal Lobe & Not Seizure Free (IV) & Bad outcome \\
\hline 14 & $11-20$ & $11-20$ & $\begin{array}{l}\text { Left Anterior Temporal Lobe } \\
\text { Amygdalohippocampectomy }\end{array}$ & Not Seizure Free $(V)$ & Good outcome \\
\hline 15 & $1-10$ & $1-10$ & Left Parietal Lobe & Not Seizure Free (IV) & Bad outcome \\
\hline 16 & $1-10$ & $1-10$ & Right Frontal Lobe & Not Seizure Free (IV) & Bad outcome \\
\hline 17 & $31-40$ & $31-40$ & Left Temporal & Not Seizure Free $(V)$ & Bad outcome \\
\hline 18 & $21-30$ & $21-30$ & Left Temporal Lobe & Not Seizure Free $(V)$ & Bad outcome \\
\hline 19 & $1-10$ & $1-10$ & Left Frontal Lesion & Not Seizure Free $(V)$ & Bad outcome \\
\hline
\end{tabular}

\footnotetext{
*Correspondence: jdauwels@ntu.edu.sg
}

'School of Electrical and Electronics Engineering, Nanyang Technological

University, Singapore

Full list of author information is available at the end of the article 
models with appropriate parameter setting and patients specific connectivity allows an exciting opportunity to make predictions based on the model dynamics.

In this study, non-seizure (inter-ictal) epoch of electrographic recording has been used to calculate the functional synchrony between different cortical regions. This synchrony measure was then used as the connectivity parameter in a computational model of transitions to a seizure like state. Hypothesizing that the network synchrony plays an important role in determining the likelihood of surgical success, we retrospectively analyzed 19 patients having intractable epilepsy, who underwent surgical treatment to achieve seizure freedom. All data were collected confirming to ethical guidelines and under protocols monitored by the local Institutional Review Boards according to NIH guidelines.

Building upon the computational model in [1], the regions which were more likely to transit into a seizure like state were delineated. It was found that these regions are correlated with those identified by clinicians as the seizure onset zone. Moreover, it was found that the resection of these regions in the model reduces the overall likelihood of a seizure. The likelihood of a surgical success was calculated in silico by iteratively increasing the area of resection and the surgical outcomes were successfully predicted for 14 out of 19 patients.

The methods presented here may aid clinicians to delineate the seizure focus. Moreover, it may facilitate neurosurgeons in predicting the likelihood of a surgical success and to investigate alternative cortical tissues to operate on if the seizure focus is in the eloquent cortex.

\section{Acknowledgements}

This work is funded in part by MOE Academic Research Funding Tier $1 \mathrm{grant}$ M4010982.040.

\section{Authors' details}

${ }^{1}$ School of Electrical and Electronics Engineering, Nanyang Technological University, Singapore. ${ }^{2}$ School of Computing Science, Newcastle University, Newcastle upon Tyne, UK. ${ }^{3}$ Massachusetts General Hospital and Harvard Medical School, Boston, MA, USA.

Published: 18 December 2015

\section{Reference}

1. Nishant Sinha, Dauwels Justin, Wang Yujiang, Cash SSydney, Taylor NPeter: An in silico approach for pre-surgical evaluation of an epileptic cortex. Engineering in Medicine and Biology Society (EMBC), 2014 36th Annual International Conference of the IEEE 2014, 4884-4887.

doi:10.1186/1471-2202-16-S1-P230

Cite this article as: Sinha et al.: Predicting surgical outcome in intractable epilepsy using a computational model of seizure initiation. BMC Neuroscience 2015 16(Suppl 1):P230.

\section{Submit your next manuscript to BioMed Central} and take full advantage of:

- Convenient online submission

- Thorough peer review

- No space constraints or color figure charges

- Immediate publication on acceptance

- Inclusion in PubMed, CAS, Scopus and Google Scholar

- Research which is freely available for redistribution

Submit your manuscript at www.biomedcentral.com/submit 